\title{
Analysis of the Impact of Teacher Program Direktorat PSMK(SM3T Program) to Animo Learning Students in Biological Lessons In SMKN 1 Kintamani, Bali
}

\section{(Analysis of the Impact of Teacher Program Direktorat PSMK(SM3T Program) to Animo Learning Students in Biological Lessons In SMKN 1 Kintamani, Bali)}

\author{
Ervan Johan Wicaksana ${ }^{1}$, Pramana Atmadja ${ }^{2}$ \\ Email: $\underline{\text { ervan_jw@unja.ac.id; pramanaatmadja@stkipngawi.ac.id }}$ \\ 1) Dosen Universitas Jambi \\ 2) Dosen STKIP PGRI Ngawi
}

\begin{abstract}
This analytic descriptive study aims to determine the impact of the accompanying teacher of the SM3T program towards on the learning interest of the students in biology subject at SMKN 1 Kintamani, Bangli, Province of Bali. Data collection methods with observation, questionnaires and interviews. Data were analyzed by quantitative descriptive. The results of the regression analysis between the presence of the accompanying teacher and the learning interest of the students in Biology subject get a determination value of 0.28 . These data indicate that $28 \%$ of the learning interest of students at SMK 1 Kintamani is influenced by the presence of a companion biology teacher in the Direktorat PSMK program.
\end{abstract}

Abstrak. Penelitian deskriptif analitik ini bertujuan untuk mengetahui dampak program guru pendamping Direktorat PSMK (Program SM3T) terhadap animo belajar peserta didik pada mata pelajaran biologi di SMKN 1 Kintamani, kabupaten Bangli, Propinsi Bali. Metode pengumpulan data dengan observasi, angket dan wawancara. Data dianalisis dengan deskriptif kuantitatif. Hasil analisis regresi antara adanya guru pendamping dengan animo belajar peserta didik pada mata pelajaran Biologi mendapatkan nilai determinasi sebesar 0,28. Data tersebut menenuntukkan bahwa $28 \%$ animo belajar peserta didik di SMKN 1 Kintamani dipengaruhi oleh adanya guru biologi pendamping pada program Direktorat PSMK.

Kata Kunci: Guru Pendamping, Program Direktorat PSMK, Animo Belajar

\section{INTRODUCTION}

In line with the progress of science, technology and development that is happening in the world more rapidly, especially in developed countries, especially countries in Europe, the Indonesian state is also required to create reliable Human Resources (HR) with developing concepts and quality so they can creating useful breakthroughs in managing natural resources and the environment around the place of residence, so that they can provide the greatest benefit for the welfare of all humans, especially for the surrounding population. Effendi, T.N. (1995) states that in addition to Natural Resources and technology, human resources are the main supporting element in the development process. Realizing the above facts, the government pays great attention to education as a human resources printer with several important policies, namely the fulfillment of the education budget of $20 \%$ of the APBN / APBD according to the demands of the law, gradually increasing compulsory education for citizens. After succeeding in the compulsory 6-year compulsory education in 1994 and the 9-year fair completion that had been successful in 2009, the Government of Bali Province has now pioneered 12 years. Another policy is to change the 
proportion (proportion) of the number of SMK students to be more than high school students with a target ratio of 67\%: 33\% in 2014.

In order to accommodate the public's interest in attending vocational education, the capacity in vocational schools must be increased. Increasing the capacity of SMKs is between $25 \%$ - 100\% through optimizing available resources. This capacity increase applies to state and private vocational high schools. Considering the development of vocational capacity capacity of this vocational school requires very large costs, then in the next 5 years, many of which are encouraged to be improved are state vocational schools. In accordance with the demands of his work and having the ability to develop themselves. Vocational education aims to improve intelligence, knowledge, personality, noble character, and the skills of students to live independently and follow further education in accordance with their vocational programs. In order to work effectively and efficiently and develop skills and skills, they must have high stamina, master their fields of expertise and the basics of science and technology, have a high work ethic, and be able to communicate well (Nurfani SU, Sumarno \& Adi Rahmat. (2006).

In line with the government's objectives mentioned above, one of the programs organized by the Directorate of Vocational Development in the 2009/2010 fiscal year is the Assistance Program for Vocational Schools. This program aims to help in overcoming the shortage of teaching staff, especially in Vocational Schools (SMK), which have not yet been established. The Directorate of Vocational Development has collaborated with several competent universities to empower students or alumni to be able to take part in programs organized by the Directorate of Vocational Development.

The main task of implementing this vocational assistance program is to teach according to the skills program needed at the vocational school. In addition to the main task there are also several other tasks or additional assignments for the accompanying teacher, namely being asked to assist the Vocational School in activities, such as: 1) Structuring the school administration system; 2) Improvement of learning media; 3) Improvement and arrangement of libraries; 4) Structuring a clean and healthy school environment; 5) Development of school extracurricular activities.

\section{RESEARCH METHODS}

This type of research is correlation research. The research subjects were students of class X, XI and XII of SMK 1 Kintamani on Biology subjects. Sugiyono. (2007) Methods of data collection using the method of observation, questionnaires and interviews. This study uses nonequivalent control group design, which can be seen in table 1.1 below. 
Tabel 1.1. Desain Penelitian

\begin{tabular}{|c|l|c|c|c|}
\hline Class & Group & Pre-test & Treatmet & Post -test \\
\hline THPP & Eksperimen & $\mathrm{O}_{1}$ & $\mathrm{X}_{1}$ & $\mathrm{Y}_{2}$ \\
\hline $\begin{array}{c}\text { BD } \\
\mathrm{T}\end{array}$ & Kontrol & $\mathrm{O}_{3}$ & $\mathrm{X}_{2}$ & $\mathrm{O}_{4}$ \\
\hline
\end{tabular}

The data of this study were analyzed by using the Pearson product moment correlation formula:

$r_{x y}=\frac{n \sum X Y-\left(\sum X\right)\left(\sum Y\right)}{\sqrt{\left\{n \sum X^{2}-\left(\sum X\right)^{2}\right\}\left\{n \sum Y^{2}-\left(\sum Y\right)^{2}\right\}}}$

$\mathrm{r}_{\mathrm{XY}}=$ product correlation coefficient moments between the scores of each

$\Sigma \mathrm{X}=$ the number of scores for each item.

$\Sigma \mathrm{Y}=$ total score

$\mathrm{N}=$ total respondent (James. A. (1973).

The subjects of the study were 6 classes at Kintamani 1 Vocational High School from class $\mathrm{X}, \mathrm{XI}$ and XII in two majors, namely the department of THPP (Agricultural Processing Technology) and majors in BDT (Animal Husbandry).

\section{DATA \& DISCUSSION}

In the vocational teacher mentoring program, the main activity carried out by the accompanying teacher is teaching. In this study, there were obstacles to learning in SMK 1 Kintamani at this time, including the lack of enthusiasm of students due to the absence of a handbook for students, so the teacher had to provide a complete record (dictate) students. This situation causes teaching and learning activities to be rather late because time is spent on reviewing or giving notes to students. Students are rarely asked to photocopy books or looking for other learning resources, for example from the internet. Because there is no internet at 1 Kintamani Vocational School, there is no internet in Belantih village. Even if there is an internet shop where it is far away, so it is difficult to reach by students (Ervan Johan. (2009).

Another obstacle about the learning process in SMK 1 Kintamani is the learning method used by teachers often uses the DI method, so it is not uncommon for learning to be teachercentered (teacher center). Thus, SMK 1 Kintamani is still not fully able to increase public interest because there are still many teacher-centered learning. The accompanying teacher who was assigned to anaze the shortcomings in the teaching and learning process at SMK 1 Kintamani managed to map several constraints. From the results of giving the first pre-test questionnaire, the data on student learning interest is lacking, which can be seen in the table as follows: 
Table 1.2 Value of Pre-test Questionnaire Percentage I

\begin{tabular}{|c|c|c|c|}
\hline No & Interest in Learning & Frequency & Percentage \\
\hline 1 & Sangat Tinggi & 0 & $0 \%$ \\
\hline 2 & Tinggi & 4 & $5,41 \%$ \\
\hline 3 & Sedang & 15 & $20,27 \%$ \\
\hline 4 & Rendah & 44 & $59,46 \%$ \\
\hline 5 & Sangat Rendah & 11 & $14,86 \%$ \\
\hline
\end{tabular}

After knowing the existence of the above problems, the accompanying teacher mapped out the problems that caused the low interest of students, among others:

a. There is no adequate book in the process of teaching and learning, especially in Biology.

b. There is no Biology laboratory at the school.

c. There is no learning media that is relevant to biological materials

d. The absence of computer facilities that have an internet network, except from handphones or smarthphones.

e. Not infrequently the learning is centered on the teacher (teacher center).

From these problems the accompanying teacher activities are focused on finding solutions to deal with the above problems, including :

a. Creating learning resources as well as interesting learning media using power point media and LCD projectors. With the existence of interesting learning media can provide a different learning atmosphere.

b. Make and present learning videos on biology learning material that cannot be directly observed.

c. Use variations of learning models that are fun and student centered. Learning models used in the learning process, namely: Student Team Achievement Division (STAD), Numbered Head Together (NHT), Think Pair Share (TPS), Jigsaw, Guided Inquiry (GI), Snowball Throwing, Mind Mapping, Team Game Tournament (TGT) dan Problem Solving.

By giving a solution from the accompanying teacher to get a very good response, as evidenced by the results of interviews with students. Students feel more enthusiastic in following the learning process. Boredom, boredom, sleepiness and lack of understanding always decrease. This is felt almost by all students both class X, XI and XII majoring in THPP (Agricultural Processing Technology) and majors in BDT (Animal Husbandry). From the results of the second post-test questionnaire the data on student learning enthusiasm was obtained, which can be seen in the following table: 
Table 1.3 Post-test Questionnaire II

\begin{tabular}{|c|c|c|c|}
\hline No & $\begin{array}{c}\text { Interest in } \\
\text { Learning }\end{array}$ & Frequency & Percentage \\
\hline 1 & Very high & 8 & $10,81 \%$ \\
\hline 2 & High & 12 & $16,21 \%$ \\
\hline 3 & Medium & 27 & $36,49 \%$ \\
\hline 4 & Low & 20 & $27,03 \%$ \\
\hline 5 & Very Low & 7 & $9,46 \%$ \\
\hline
\end{tabular}

From the research data that has been obtained then analyzed with quantitative descriptive. The results of the regression analysis between the existence of accompanying teachers and the interest in learning of students in Biology subjects get a determination value of 0.28 . The data shows that $28 \%$ of students' interest in learning at SMK 1 Kintamani is influenced by the existence of companion biology teachers in the Directorate of Community Participation.

\section{CONCLUSION \& ADVICE}

\subsection{Conclusion}

The results of the regression analysis between the existence of accompanying teachers and the interest in learning of students in Biology subjects get a determination value of 0.28. The data shows that $28 \%$ of students' interest in learning at SMK 1 Kintamani is influenced by the existence of companion biology teachers in the Directorate of Community Participation.

\subsection{Suggestion}

1. To all teachers who teach to apply the right method to each learning material, so that all students can be active in receiving lessons.

2. For learning in the outermost, foremost and remote areas if learning infrastructure is still not available, it is better to be able to be creative using existing materials and equipment to increase student interest in learning.

3. To the relevant offices to pay attention to the lack of facilities, both facilities and infrastructure needed at school. 


\section{REFERENCE}

Borg, Walter R. \& Meredith Damien Gall. (1983), Educational research, an introduction fourth edition, LongmanCaporaso

Effendi, T.N. (1995). Sumber daya manusia, peluang kerja dan kemiskinan. Yogyakarta: PT. Tiara Wacana Yogya

Emzir. (2009). Metodologi penelitian pendidikan, kuantitatif dan kualitatif. Raja Grafindo Persada: Jakarta.

Ervan Johan. (2009). Laporan program guru pendamping di SMKN 1 Kintamani, Bali. UNESA: Surabaya

James. A. (1973). Quasi-experimental approaches to social science dalam quasi-experimental approaches (ed. James A. Caporaso \& Leslie L. Roos Jr), Northwestern University PressCook.

Nurfani SU, Sumarno \& Adi Rahmat. (2006). Metodologi penelitian untuk peningkatan kualitas pembelajaran penelitian kuasi eksperimen dalam PPKP, Direktorat Ketenagaan Direktorat Jendral Pendidikan Tinggi Departemen Pendidikan Nasional

Sugiyono. (2007). Metode penelitian kuantitatif, kualitatif dan R\&D. Alfabeta: Bandung. 